\title{
Mobile Banking in the Government-to-Person Payment Sector for Financial Inclusion in Pakistan
}

\author{
Atika Ahmad Kemal \\ Lord Ashcroft International Business School, Anglia Ruskin University, Chelmsford, UK \\ atika.kemal@anglia.ac.uk
}

\begin{abstract}
Whilst there have been growing interest and efforts by governments in developing countries to disburse digital government-to-person (G2P) payments to promote financial inclusion, the role of mobile banking in the receipt of social cash remains under-researched. Through an interpretive case study of the Benazir Income Support Programme (BISP) in Pakistan, this paper applies Orlikowski's Duality of Technology that critically examines mobile banking usage by women beneficiaries and technology's effects on the institutional properties of their households. Qualitative data were collected through semi-structured interviews from participants located in Pakistan. The findings highlighted that mobile banking enabled women to receive the full amount of grants, securely and conveniently, from agents. However, mobile banking imposed human, socioeconomic and technological constraints which restricted women's access to and usage of financial services that limited financial inclusion. Women were socially and politically empowered, thereby, social inclusion was transformative. This paper theoretically contributes to the Duality of Technology framework that was deterministic for women beneficiaries. The study accentuates the redesign of mobile banking to match women's capabilities, and imparting financial and digital training to them. Also, the provision of a range of financial resources to beneficiaries may steer micro-entrepreneurial activities to advance the inclusion agenda in Pakistan.
\end{abstract}

Keywords: Mobile banking; G2P payments; social cash; financial inclusion; social inclusion; duality of technology; Pakistan

\section{Introduction}

Nowadays, many governments are leveraging on digital technologies for disbursing government-to-person (G2P) payments, as a vehicle to advance the financial inclusion agenda in developing countries. G2P payments include social cash, wage and pension payments to an estimated 170 million people worldwide (Rotman, 2011). The broad reach of these payments deploys digital technologies, such as mobile phones or card-based solutions that offer the opportunity to rapidly scale up access to financial services (Ehrbeck, 2011; Rotman, Kumar and Parada, 2013). Research from middle-income countries; Brazil, Columbia, Mexico and South Africa, provides critical insights into evaluating governments' costs, types of accounts provided to recipients and the business case in disbursing G2P payments (Pickens, Porteous and Rotman, 2009; Bold, Porteous and Rotman, 2012). Other studies confirm that the rapid development of digital platforms for making payments provides the speed, security, 
transparency and cost efficiency that supports financial inclusion at the scale expected to achieve the G20 goals (Klapper and Singer, 2014).

Digital payments are the first point of entry into the financial system for individuals and offer accounts in the form of traditional bank accounts, electronic wallets (payment cards) or mobile wallets (mobile banking). These accounts provide a store of value for undertaking financial transactions, such as payments, savings, credit and insurance (Ehrbeck, Pickens and Tarazi, 2012). Whilst the broader adoption of digitized G2P payments may provide the on-ramp to financial inclusion, challenges such as physical infrastructure, interoperability issues and capabilities of citizens may hinder governments' initiatives (Klapper and Singer, 2014). Although digital payments are routed through a bank account, there is little evidence that underscores the relation between receiving G2P payments and using financial services (Stuart, 2016). Hence, the implications that digital technologies increase poor peoples' access to and usage of financial services remain largely untapped in current studies (Pickens, Porteous and Rotman, 2009; Stuart, 2016). Moreover, there is scant research that explores the opportunities and challenges that mobile technologies provide to access G2P payments and the link to financial inclusion.

Foster and Heeks (2013) accentuate how the diffusion of mobile technologies at the BoP (Bottom of Pyramid) creates 'inclusive innovation' or 'pro-poor innovation' for the poor. However, the study overlooked the technological constraints that affected adoption and usage. Other studies evaluate the intersection of mobile technologies with social and financial networks (Baro and Endouware, 2013), but discount the role of technologies in shaping the financial landscape in poor communities (Duncombe and Boateng, 2009). The Global Findex Report (2014) compiled from 142 countries signifies that variables such as education, income and gender were associated with financial inclusion (Demirguc-Kunt et al., 2014). The findings suggested that educated people with higher incomes were primarily men - who were more financially included. This provides a rationale to study the potentials that mobile technologies provide to women in helping to increase their financial access in impoverished communities.

Nonetheless, the technological deterministic assumption that increased access to and use of digital technologies and network infrastructures would somehow lead to economic and social development is still being tested today. This indicates a shift in applying information systems models developed in Western countries to developing countries, since human, economic and social development issues are changing as technology offers new applications (Qureshi, 2014b). Scholars have therefore emphasized the importance of a situated context in which mobile technologies are designed and 'embedded' to enable or constrain the developmental efforts (Qureshi, 2014a). This is essential to consider, as development theorists usually look at Information Communication Technology (ICT) transfer and diffusion as actions entangled with conflicting interests and power within global and national politics (Thompson, 2008; Avgerou, 2010). So, while implementing m-banking projects in support of the United Nations Millennium Development Goals (MDGs) for poverty eradication, governments, policy makers and practitioners need to understand the importance of the local context in shaping practices for users (Qureshi, 2014a). 
As research in the government sector on the use of digital technologies for making G2P payments is scarce, this paper evaluates the usage of m-banking for receiving social cash payments and its link to financial inclusion in poor households. Hence, this paper aims to critically explore the role of m-banking within a government social cash programme - the Benazir Income Support Programme (BISP) in Pakistan that targets women only as beneficiaries. Although the program deploys other digital tools for receiving BISP payments, this study is limited to analyzing the usage and effects of m-banking only. The research questions investigated in this study are:

\section{1) How does m-banking enable and/or constrain women beneficiaries to access G2P payments from BISP?}

\section{2) How does m-banking have an effect on the institutional properties of households for financial inclusion?}

In what follows, Section 2 defines the mobile banking model in this paper. Section 3 justifies the theoretical framework - Orlikowski's Duality of Technology (DoT) as a theoretical lens that locates the research questions. Following this, Section 4 highlights the research context of the G2P sector in Pakistan and the case study of the BISP as a methodology in this study. Section 5 presents the findings after analyzing the qualitative data collated from interviews. In Section 6 , the findings are discussed in light of DoT. Finally, in Section 7, the conclusions shed light on the contributions and practical implications of this study for governments, policy-makers and m-banking providers in order to promote inclusive innovation in Pakistan.

\section{Defining Mobile Banking in Developing Countries}

The exponential growth and diffusion of mobile technologies in the developing world have revolutionized the banking sector. However, the majority of people in developing economies are unbanked, creating an inequitable economic world that impacts on individual's social and economic well-being (Donner and Tellez, 2008; Duncombe and Boateng, 2009). Since there are more people with mobile phones than with bank accounts (Porteous, 2006), banks exploit mobile technologies to deliver financial services, via mobile banking (m-banking) to financially marginalized and remote populations in developing countries (Mas, 2009).

Most studies from developing countries distinguish between a range of $\mathrm{m}$-banking practices: person-to-person $(\mathrm{P} 2 \mathrm{P})$, person-to-business $(\mathrm{P} 2 \mathrm{~B})$ and government-to-person $(\mathrm{G} 2 \mathrm{P})$ payments, in addition to mobile saving and mobile credit/insurance (Porteous, 2007; Mas, 2009; 2012). However, the terms mobile finance, mobile money and mobile banking have been used synonymously in the literature as pointed out by authors (Donner and Tellez, 2008; Firpo, 2009). While there are no universally accepted definitions, it becomes critical to justify the terminology for m-banking as applied in this study. So in an attempt to create some clarity around terminology, the definition for $\mathrm{m}$-banking is based on papers from Consultative Group 
to Assist the Poor (CGAP, 2010; 2012) and Group Spéciale Mobile Association (GSMA, 2014).

The most common definition of m-banking is identified as an extension of online or electronic banking services onto a mobile device (smart phone, tablet, etc.) enabled by wireless protocols. However, this definition is limited to 'banked' customers only. It allows customers the anywhere anytime convenience to use their mobile phone for banking services, such as deposits, withdrawals, account transfer, bill payment and balance inquiry (Wessels and Drennan, 2010; Cruz et al., 2010). Such m-banking applications in developed economies are additive in that they provide an alternative delivery channel to the existing bank customers. In developing economies, transformative models based on branchless banking also exist which integrate 'unbanked' customers into the formal financial sector (Porteous, 2007; Firpo, 2009).

This paper subscribes to the m-banking definition based on the branchless banking model (CGAP, 2010; 2012). Branchless banking is the delivery of financial services outside bank branches, using agents and information and communications technologies, such as mobile phones or card-based solutions, to transmit transaction details. Thus, branchless banking regulations provide an enabling environment for m-banking, as agents act on behalf of banks for 'cashing in' and 'cashing-out' transactions (Ivatury and Mas, 2008). Banking agents are more accessible in remote communities where traditional bank branches are absent, either due to infrastructural deficits or high costs (Mas, 2009). Consequently, m-banking can increase poor people's access to financial services if regulation (i) permits the use of a wide range of agents outside bank branches, thereby increasing the number of service points, (ii) eases account opening (both on-site and remotely) while maintaining adequate security standards and (iii) permits a range of players to provide payment services and issue mobile money (CGAP, 2010; GSMA, 2014; Shaikh and Karjaluoto, 2015).

However, the distinction between mobile money and m-banking is seen to be blurred in the literature (Firpo, 2009). It is therefore important to outline the rationale for using m-banking in this paper. Under branchless banking, mobile money does not require recipients to have a bank account, and 'over-the-counter' transactions (cash-in and cash-out) are performed through agents - commonly known as agent-led banking. Conversely, m-banking offers accounts to unbanked customers who store mobile money in mobile wallets (Firpo, 2009; GSMA, 2014). Customers are still reliant on banking agents or retailers for the conversion of mobile money to physical cash and vice versa (Mas, 2012). While m-banking permits customers to engage in a range of financial transactions, checking balance, payments, savings and credit, it is generally noted that most G2P studies adopt the term 'm-banking' for withdrawing grants (Rotman, Kumar and Parada, 2013; BISP Report, 2014). This is justified because m-banking 'banks the unbanked' even though mobile payments are received in accounts with limited functionality (Bold, Porteous and Rotman, 2012).

Mas (2012) identifies that the market for transferring welfare payments by government programs is mostly tapped by larger banks to increase financial outreach and serve wider populations. Governments typically contract with banks, who partner with mobile network 
operators, under various business arrangements for disbursing payments into beneficiaries' accounts (Vincent and Cull, 2011). In the delivery of grants through m-banking, a text message, which embeds a unique personal identification number (PIN), is sent to a beneficiary's mobile phone. This notification informs the beneficiary that a payment has been transferred to the mobile account which may be collected from an agent or retailer. The agent first validates the beneficiary's identity, through biometric identification, and then hands over the money (Emmett, 2012; Oberlander and Brossmann, 2014). One primary reason for the private sector involvement is that without their expertise and technological infrastructure, it is difficult for governments to transfer G2P payments independently (Oberlander and Brossmann, 2014). Furthermore, research indicates that mobile technologies provide low-cost solutions for governments to extend the outreach of G2P payments, and thereby, 'bank' financially underserved communities (Ehrbeck, Pickens and Tarazi, 2012; Bold, Porteous and Rotman, 2012).

However, research on G2P payments, in particularly social cash payments, disbursed via mbanking channels, remains scant from low income countries. Although studies highlight how Banco Davivienda in Columbia used Daviplata to disburse G2P payments, there was little evidence to suggest technology's link to financial inclusion (Almazan, 2013). In Malawi, Airtel, on behalf of Save the Children and the World Food Programme, distributed G2P payments to 23,000 families through Airtel Money, but owing to the small scale of the project, the effect of m-banking on financial inclusion indicators was insignificant (Almazan, 2013). Furthermore, the Disarmament, Demobilisation and Reintegration (DDR) Programme in the Democratic Republic of Congo paid monthly demobilization to retired soldiers through mbanking channels. However, the program was ineffective, as recipients resided in villages situated beyond the reach of the country's financial system (Bankable Frontier Associates, 2009).

\section{Theoretical Framework - The Duality of Technology}

Orlikowski's Duality of Technology (1992) extends the concepts in Giddens' structuration theory $(1990 ; 1991)$ to offer a dialectical understanding between technology, social agents and institutions. By reconceptualizing the scope and use of technology, the theoretical lens of Duality of Technology (DoT) affords new insights to investigate m-banking usage by women beneficiaries and its effects on restructuring households in the study.

Orlikowski's Duality of Technology (1992) is a well-established framework in the ICT literature for understanding the structuration of technology (Pinsonneault and Kraemer 2002; De' and Ratan, 2009). Sjoberg (2013) contributes to an understanding of issues and factors that might influence individuals and organizations in their use of, and capabilities to adapt and create, a 'new sense' of social media networks. The study by Mota and Rodrigues Filho (2011) evidences how e-procurement is a subjective element, sometimes understood inconsistently by human agents in different organizational contexts. Users appropriate the rules, knowledge and assumptions into the new system to perform certain tasks affirming to the status quo. Bras et 
al. (2016) explore the interaction between ICT and business improvement. They highlight the factors that have an enabling or inhibiting effect on business and accentuate the need for a situational and specific understanding of the context. On the other hand, Blackwell (2014) examines the dynamic relationship between social institutions, teachers and technology in early childhood classroom teaching. He emphasizes the importance of student-centered philosophies in interactions with new learning technologies in the classroom.

Despite the application of Duality of Technology as a theoretical lens in past studies, its novelty remains for interpreting complex m-banking practices in the G2P sector. In this paper, DoT situates the research questions for the study. It helps to analyze the interactions between G2P recipients', or women beneficiaries' with m-banking and institutions (households). This is because households possess authoritative, established rule-like procedures with a selfsustaining character, or those social patterns that when chronically reproduced, owe their survival to relatively self-activating social processes (Avgerou, 2002). Hence, by sharing similar structural traits with institutions, households may be classified as 'social organisations' (Avgerou, 2002). This justifies the application of the framework as a powerful lens in evaluating the enabling and/or constraining effects of m-banking on women beneficiaries and the institutional effects on household properties for financial inclusion. Hence, DoT aims to contribute toward a new theoretical understanding in explaining the complex relationship between technology, social actors and institutions.

In Figure 1, Orlikowski's model (1992) presents four key relationships that operate continuously and simultaneously in the interactions between technology, people and organizations. The first interaction is 'Technology is a product of human action' (process a). This relationship signifies that technology is 'socially constructed' by designers and encapsulates the social and institutional beliefs of the creator. It also denotes that once constructed, technology is adopted and used by users. However, the 'duality of technology' theorizes that after construction, technology becomes part of the objective institutional properties of the organization unless it is enacted by social agents, or users. Users, through continuous interaction and use, improvise and sustain certain technological practices. Thus, technology is 'interpretively flexible' through its ongoing appropriation by social actors (Orlikowski, 1992). 


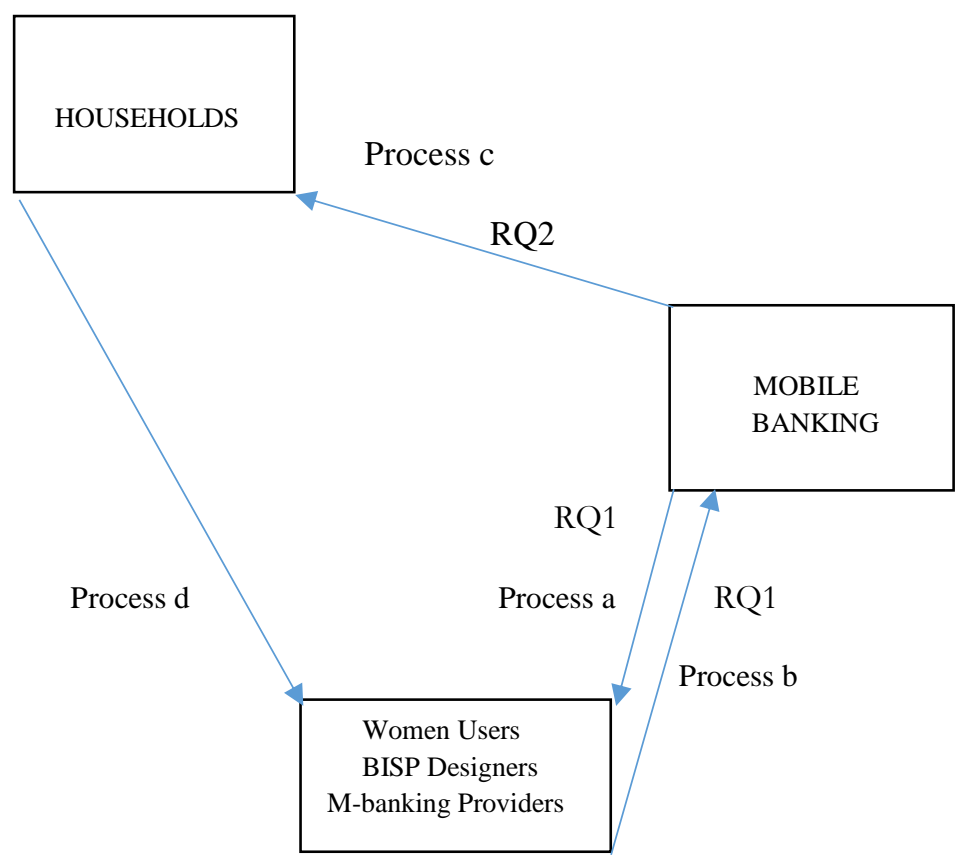

Figure 1. Relationship between Orlikowski's Duality of Technology and Research Questions. Adapted from Orlikowski (1992).

Within the second relationship, 'Technology is a medium of human action' (process b). Orlikowski (1992) postulates that technology, enacted through human agency, does not 'determine' but only 'conditions' human practices. Hence, technology may 'enable' and/or 'constrain', or do both. So, despite being a product of human action, technology has its effect on users, unless users 'choose to act otherwise' (Orlikowski, 1992).

In relation to this study, 'process a' and 'process b' (figure 1) locate the first research question, 'How does m-banking enable and/or constrain women beneficiaries to access $G 2 P$ payments?'

The third influence, 'Institutional impact of technology on structures' (process c) underpins how technology affects the institutional properties of organizations for structural change. Hence, this process defines the manner in which technological practices become reified and institutionalized in social structures or households (Avgerou, 2002). The enabling and/or constraining effects of technology may either reaffirm or disrupt the institutional status quo of social actors (Orlikowski, 1992).

In the context of my study, 'process c' (figure 1) situates the second research question, 'How does $m$-banking have an effect on the institutional properties of households for financial inclusion?' 
In the final relationship, 'Institutional impact of technology on agents' (process $d$ ), human actors are subject to the institutional properties of their context. They draw upon resources, stocks of knowledge and normalized standards for legitimizing the construction of technological practices (Orlikowski, 1992). Also, technology designers draw upon resources, experiences, norms and meanings from their institutional context that recursively instantiates the rules and resources that affect their social actions (Orlikowski, 1992). Since this relationship looks at the construction of technology, it lies outside the scope of analysis in this study.

Hence, Duality of Technology presents a composite research framework that structures this study, as a sensitizing device for conducting empirical research. The theoretical concepts operate at a high level of abstraction and offer an explication of the logic of research into social activities rather than as a source of testable propositions. Although different streams of IS research offer conflicting perceptions on the scope and role of technology in underscoring the philosophical contradictions between the subjective and objective realms that dominate IS research (Jones, 1999; Jones, Orlikowski and Munir, 2004; Jones and Karsten, 2008), DoT affords a unique interpretive lens to illumine the data.

In the context of this study, DoT illuminates how technology or m-banking is used, enacted and appropriated by social actors (women beneficiaries) whilst conditioning their practices. In doing so, it examines how the enabling and/or constraining effects of technology impact on the institutional properties of households for structural change or financial inclusion. Thus, by combining m-banking innovation with the developmental outcomes, the framework examines the implications of m-banking for transforming the socio-economic dynamics of $\mathrm{G} 2 \mathrm{P}$ households in Pakistan.

\section{Research Context and Methodology}

\subsection{Mobile Banking in the G2P Sector in Pakistan}

Pakistan, a developing country with a population exceeding 190 million, boasts of a high mobile phone penetration of $73 \%$ (Pakistan Economic Survey, 2014/15). However, $88 \%$ of the total population is unbanked and financially marginalized, out of which $63 \%$ of the population resides in rural communities (World Bank, 2014). There is consensus amongst policy-makers to increase financial access through financially inclusive banking practices (Anwar, 2013).

Currently, five established m-banking service providers offer a range of mobile financial services in Pakistan: Easypaisa, UBL-Omni, Mobicash, Timepey and U-fone. Branchless banking regulations, issued in 2008, by the State Bank of Pakistan provide licenses to banks only. Hence, m-banking is bank-led and is supported by a range of business model arrangements with mobile operators (CGAP, 2011; 2012). According to Rotman, Kumar and Parada (2013), 
Pakistan serves as an example of how public and private institutions together can move a country towards a 'digital financially inclusive system'. Government and public actors have created the enabling environment and have provided seed funding, while private actors are developing the infrastructure, services and a long-term business case (Rotman, Kumar and Parada 2013).

Moreover, branchless banking regulations have enabled the government sector in Pakistan to digitize a large share of G2P flows. This enables the government to implement digital platforms for distributing a range of services: pensions, salaries and social cash to steer the country toward a financially inclusive system. Within the branchless banking framework, m-banking may promote financial inclusion if (1) G2P payments land into accounts enabling recipients to store and use funds for financial transactions and (2) financial services are accessible to recipients in terms of cost and proximity. This paper aims to highlight the benefits and challenges of women beneficiaries' usage of mobile technology for receiving digital social cash, and whether technology connects them to the financial system to undertake other economic activities. As highlighted by Pickens, Porteous and Rotman (2009),

More vigorous research is needed to track how G2P recipients use financial services when connected to the financial system and whether it encourages any form of entrepreneurial development (Pickens, Porteous and Rotman, 2009).

\subsection{Case Study Methodology- The BISP}

The methodology is case study research (Walsham, 2006; Yin, 2009) of the BISP in Pakistana social cash program launched in 2008 by the former Pakistan People's Party Government. BISP is the first ever comprehensive, universal and transparent social safety program that is the flagship program of the Pakistani Government to achieve the United Nations MDGs. The concept of BISP is derived from the broadly acknowledged developmental theories of social protection widely implemented in the developing and developed world (BISP Report, 2014).

BISP was established through an Act of Parliament under the executive patronage of the Prime Minister, while the President of Pakistan is the Chief Patron. The program, executed through an organization, is headed by a board with a nominated chairperson and an executive committee. The committee comprises of a secretary and cabinet members from the finance, economic and foreign affair ministries, in addition to non-government members. The Head Office is located in the Federal Capital - Islamabad, with six regional offices at four provincial capitals and offices in Azad Jammu and Kashmir and Gilgit Baltistan. There are approximately 31 divisional offices and 352 tehsil offices across the country (BISP Report, 2014).

The BISP aims to cushion the effects of chronic poverty and mitigate the impacts of rampant inflation of food and fuel prices on poor households. Over the years, it has successively become the country's main safety net program. BISP provides monthly cash transfers of value Pakistani Rupees (PKR) 1500 (approximately \$14.25 per month) that are received quarterly by around 5.3 million women from low-income households (BISP Report, 2014). Recent data 
suggest that one-third of households in Pakistan are falling below the poverty line, while $21 \%$ are severely poor (SDPI Report, 2012). Women, who belong to the most underprivileged and vulnerable sections of society and live in abject poverty, with monthly incomes less than PKR 6000 (\$57), are eligible for BISP payments. By targeting women, as household heads, BISP also aims to socially empower women. Economic deprivation, regardless of political affinity, racial identity, geographical location and religious beliefs, is the sole criterion for enrolling women in the program from all provinces and regions: Sindh, Punjab, Baluchistan, Khyber Pakhtoonkhwa, Federally Administered Tribal Areas (FATA), Azad Jammu and Kashmir (AJK), Gilgit Baltistan (GB) and Islamabad Capital Territory (BISP Report, 2014).

BISP holds the largest database of underprivileged families in Pakistan - recorded by the National Database and Registration Authority (NADRA) after conducting the largest and first ever door-to-door poverty survey. The poverty score card survey, introduced in October 2010, was the first of its kind in South Asia. It assisted BISP to objectively identify 7.7 million households which were 'poorest of the poor' (BISP Report, 2014). The poverty score card was designed with financial and technical support from the World Bank and the Department for International Development (DFID), UK. Based on a proxy means test, it determined the welfare status of households - in relation to size, asset ownership and education of household members. Moreover, the poverty score card recorded Global Positioning System readings for households. This increased the survey's accuracy, objectivity and replicability for devising emergency strategies in future (BISP Report, 2014). The data are used for planning of pro-poor development policies and programs and is shared through protocols with various international and national organizations. BISP's operational design, separation of function and innovative technology-based mechanism have inspired other developing countries: Bangladesh, India, Ghana, Mongolia, Cambodia and Nepal, to implement similar programs to improve the livelihoods of their millions of poor citizens (BISP Report, 2014).

Initially, when BISP was launched in 2008, there was an absence of reliable data to identify underprivileged households. The task of targeting poor households was entrusted to parliamentarians who selected 'handpicked' households. BISP provided an equal number of application forms to parliamentarians (800 forms to each member of the National Assembly and Senate and 1000 forms to each member of Provincial Assemblies) who identified beneficiaries in their respective constituencies. The forms were verified by NADRA's database, and initially, 2.2 million families received cash transfers (BISP Report, 2014).

In 2010, the first transition in the program was related to objective targeting of beneficiaries, following the introduction of the poverty score card. Survey enumerators visited each household, or selected a central location in the village or community, where the majority of citizens flocked in the communal spaces to get their score card forms filled by enumerators. As enumerators had no particular affiliation with a specific political party, this targeting system enrolled eligible beneficiaries onto the program. The poverty score card was neutral to specific qualitative dimensions of marginality and exclusion, including local power relations, status, kinship, provincial identity and religious minority, which registered genuine beneficiaries. This was a rare instance of a social intervention that proactively and impartially reached out to all deserved households in Pakistan. 
The second transition entailed the delivery of welfare payments. Previously, payments were delivered either in cash by politicians, or through money orders by postmen. These middlemen demanded 'baksheesh' (bribes) from women to ensure the future delivery of payments at home. In 2010, after the introduction of the poverty score card, BISP shifted to digital platforms for disbursing payments - via technologies including smart cards, mobile phones and debit cards. Nonetheless, the use of digital payments attempted to deliberately side-step the role of local patrons or politicians within the grant disbursement process. Many parliamentarians resisted the change, as the execution of digital solutions stripped their political powers, and thereby, diminished their control, popularity and authority in their regional constituencies. Hence, shifting to digital payment platforms introduced transparency, visibility, security and efficiency in the grant disbursement process by eliminating the middlemen.

Furthermore, in order to receive digital payments, BISP made it mandatory for women beneficiaries to register with the NADRA which issued computerized national identification cards (CNICs) to all beneficiaries. Noticeably, even the most conservative women, observing 'purdah' (veil), stepped out of their homes to get their photographs taken and biometrics recorded for enrolling with BISP. The issuance of identity cards was an effective measure, undertaken by BISP, for the social empowerment of women.

Initially, mobile banking projects were confined to five regions of Pakistan: Islamabad, Rawalpindi, Larkana, Layyah and Battagram. In these districts, mobile phones were primarily funded by banks and mobile operators and provided free of cost to beneficiaries. However, owing to the high costs foreseen in scaling up m-banking projects across the country, mobile phones were gradually replaced by the Benazir Debit Card. These cards were seen to be more economical tools for beneficiaries to receive their grants. According to BISP Report (2014), approximately $94 \%$ of beneficiaries received payments through digital tools.

BISP is primarily funded by the Government of Pakistan and its disbursements crossed PKR. 70 billion (USD $\$ 667,908,500$ ) approximately, by the end of the financial year 2013-2015. It also receives unprecedented financial and technical support from multilateral and bilateral donor agencies such as the World Bank and DFID (BISP Report, 2014).

Figure 2 illustrates the model for disbursing G2P payments to women beneficiaries in the BISP program.

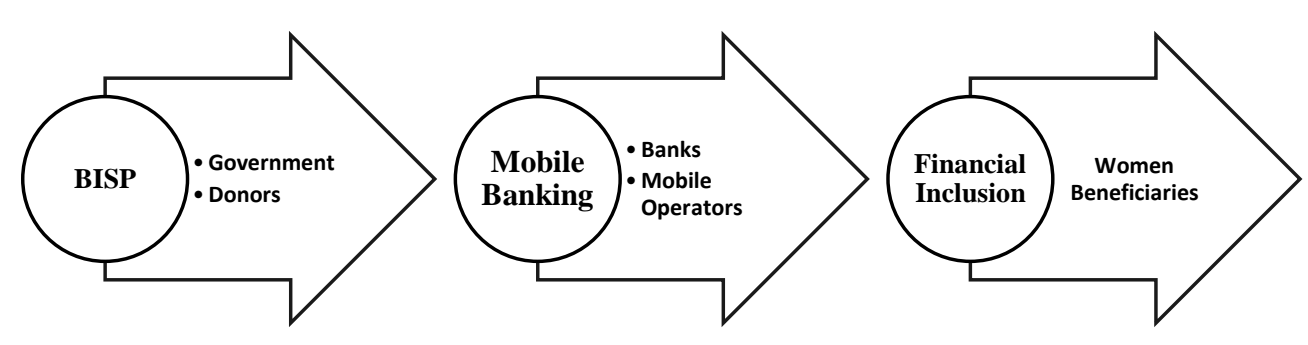

Figure 2. Mobile Banking for Delivering G2P Payments within BISP 


\subsection{Data Collection and Analysis}

Primary data were collected through qualitative methods that underpin the interpretive stance in the study (Walsham, 1995; 2006). A total of 33 semi-structured interviews were conducted between March and April 2014 in Islamabad and Rawalpindi - Pakistan. These localities were selected because m-banking was implemented in these regions. As the BISP head office and mobile operators' head offices were also located in Islamabad, this selection of research location facilitated data collection for the study.

As presented in Table 1, 16 interviews were conducted with women beneficiaries as primary units of data collection. The interviews were held at the Islamabad Field Office - the customer service site for beneficiaries residing in the semi-urban and rural clusters around Rawalpindi and Islamabad. Women, who visited the office on the day, were purposively sampled. The selection criteria included mobile phone ownership, registration with BISP for a minimum period of 18 months and residence site. In-depth interviews lasted around 60-75 minutes, were conducted in the local language, $U r d u$, and were tape-recorded after taking consent. The interview questions explored beneficiaries' perceptions and experiences of using m-banking and the effects of technology on their socio-economic livelihoods.

In addition, 17 semi-structured interviews were conducted with BISP officials (strategic management and operational roles), mobile operator staff (Easypaisa and U-fone), bankers (United Bank Limited, Alfalah Bank and Summit Bank) and international donors (DFID). All interviews with organizational staff were formal, so took place in English - the official language in the work place in Pakistan. Interviews were mostly tape-recorded with an average duration of 45-60 minutes. These participants comprised secondary units of data collection. The data obtained afforded 'data integration' to establish validity, credibility and reliability in the qualitative findings. In addition, secondary data were drawn from official documents, websites and formal and informal media sources.

Table 1. Data Sample and Methods

\begin{tabular}{|l|l|l|c|}
\hline SOCIAL ACTORS & SAMPLE & METHODS & TOTAL \\
\hline Mobile Banking Users & $\begin{array}{l}\text { Women } \\
\text { Beneficiaries }\end{array}$ & $\begin{array}{l}\text { Semi-structured } \\
\text { interviews }\end{array}$ & 16 \\
\hline Program Designers & $\begin{array}{l}\text { BISP Chairman, } \\
\text { Directors, Managers } \\
\text { and Operational } \\
\text { Staff }\end{array}$ & $\begin{array}{l}\text { Semi-structured } \\
\text { interviews } \\
\text { Official } \\
\text { documents }\end{array}$ & 9 \\
\hline
\end{tabular}




\begin{tabular}{|c|c|c|c|}
\hline & & $\begin{array}{l}\text { Formal and } \\
\text { informal media } \\
\text { sources }\end{array}$ & \\
\hline $\begin{array}{l}\text { Mobile Banking Operators } \\
\text { Easypaisa / Ufone }\end{array}$ & $\begin{array}{l}\text { Directors and } \\
\text { Managers }\end{array}$ & $\begin{array}{l}\text { Semi-structured } \\
\text { interviews } \\
\text { Documents } \\
\text { Formal and } \\
\text { informal media } \\
\text { sources }\end{array}$ & 4 \\
\hline $\begin{array}{l}\text { Banks } \\
\text { UBL / Alfalah / Summit Banks }\end{array}$ & $\begin{array}{l}\text { Executive Vice } \\
\text { President } \\
\text { Senior Managers }\end{array}$ & $\begin{array}{l}\text { Semi-structured } \\
\text { interviews }\end{array}$ & 3 \\
\hline $\begin{array}{l}\text { Donors } \\
\text { DFID / World Bank }\end{array}$ & Director & $\begin{array}{l}\text { Semi-structured } \\
\text { interview } \\
\text { Documents }\end{array}$ & 1 \\
\hline TOTAL INTERVIEWS & & & 33 \\
\hline
\end{tabular}

Prior to all interviews, a Participation Information Sheet was provided to each participant that explained the objectives of the research and the nature of information sought for the study. Ethical approval was mandatory before embarking on the study, and every participant's consent was recorded on the Participant Consent Form, in accordance with the UK Data Privacy Act 2008. After translating and transcribing the interviews, the transcriptions were uploaded into the software, NVivo, for thematic analysis (Boyatiz, 1998; Taylor and Ussher, 2001; Braun and Clarke, 2006). Although the interview template was theory-led, based on the theoretical concepts in Orlikowski's theory, other themes which emerged from the data were also analyzed. Thus, 'hybrid' thematic analysis constructed new theoretical concepts that complemented the existing framework (Boyatiz, 1998; Strauss and Corbin, 1999). Hence, thematic analysis was not restricted to a passive approach that merely discovered pre-existing themes, but a data-driven approach interpreted new themes from the data (Taylor and Ussher, 2001).

\section{Presentation of Findings}

Table 2 displays the socio-economic data from 16 women beneficiaries to understand their family structures, income, education levels and demographic traits. The data showed that 10 
out of 16 households comprised nuclear families - with an average family size of 9 members, including average 5 children per household. Majority of 14 women were unemployed so were dependent upon their husbands' incomes - average monthly income of USD \$101. Their husbands were mainly self-employed, as rickshaw drivers, builders or fruit/vegetable hawkers. Women were typically confined to domestic responsibilities rather than seeking work in capital or labor markets. On average, women participant's age was 40. Literacy levels were generally low - 9 out of 16 women were completely illiterate, 6 had received only some level of primary education, while only 1 woman had attended secondary school with a qualification equivalent to General Certificate of Secondary Education (GCSE). 
Information Technology for Development Journal

Table 2. Women Beneficiaries Socio-economic and Demographic Data

\begin{tabular}{|c|c|c|c|c|c|c|c|}
\hline & $\begin{array}{l}\text { Age } \\
\text { (Years) }\end{array}$ & $\begin{array}{l}\text { No. of Years in } \\
\text { School }\end{array}$ & $\begin{array}{l}\text { Dependent on } \\
\text { Husband } \\
\text { (Yes/No) }\end{array}$ & $\begin{array}{l}\text { No. of } \\
\text { Children }\end{array}$ & $\begin{array}{l}\text { No. of } \\
\text { Family } \\
\text { Members }\end{array}$ & $\begin{array}{l}\text { Nuclear } \\
\text { Family } \\
\text { (Yes/No) }\end{array}$ & $\begin{array}{l}\text { Monthly Income } \\
\text { (USD) }\end{array}$ \\
\hline B1 & 40 & 5 & Yes & 5 & 7 & Yes & 172 \\
\hline B2 & 50 & 5 & Yes & 6 & 8 & Yes & 67 \\
\hline B3 & 52 & 2 & Yes & 6 & 9 & No & 148 \\
\hline B4 & 54 & 0 & Yes & 6 & 9 & No & 86 \\
\hline B5 & 23 & 0 & Yes & 2 & 6 & No & 114 \\
\hline B6 & 46 & 0 & Yes & 9 & 11 & Yes & 57 \\
\hline B7 & 36 & 0 & Yes & 7 & 24 & No & 124 \\
\hline B8 & 31 & 5 & Yes & 6 & 8 & Yes & 124 \\
\hline B9 & 48 & 0 & Yes & 7 & 9 & Yes & 62 \\
\hline B10 & 41 & 5 & Yes & 5 & 7 & Yes & 67 \\
\hline B11 & 37 & 0 & Yes & 6 & 8 & Yes & 114 \\
\hline B12 & 38 & 0 & Yes & 7 & 9 & Yes & 57 \\
\hline B13 & 51 & 0 & Yes & 4 & 6 & Yes & 76 \\
\hline B14 & 31 & 5 & No & 2 & 7 & No & 138 \\
\hline B15 & 26 & 10 & No & 2 & 11 & No & 95 \\
\hline B16 & 30 & 0 & Yes & 6 & 8 & Yes & 114 \\
\hline & $\begin{array}{l}\text { Average } \\
\text { Age- } 40\end{array}$ & $\begin{array}{l}\text { Illiterate- } 9 \\
\text { Some primary } \\
\text { qualification -6 } \\
\text { GCSE } \\
\text { qualification- } 1\end{array}$ & $\begin{array}{l}\text { Dependent- } \\
14 \\
\text { Independent- } \\
2\end{array}$ & $\begin{array}{l}\text { Average } \\
\text { children } \\
-5\end{array}$ & $\begin{array}{l}\text { Average } \\
\text { household } \\
\text { members- } \\
9\end{array}$ & $\begin{array}{l}\text { Nuclear } \\
\text { family- } \\
10 \\
\text { Joint } \\
\text { family- } \\
6\end{array}$ & $\begin{array}{l}\text { Average Monthly } \\
\text { Income=USD } \\
\$ 101\end{array}$ \\
\hline
\end{tabular}




\subsection{Usage of Mobile Banking by Women Beneficiaries}

This section highlights how m-banking was used by women beneficiaries to receive social cash payments. In particular, how technology enabled and/or constrained women in relation to Duality of Technology framework (Table 3).

Table 3. Enabling and Constraining Women Beneficiaries

\begin{tabular}{|c|c|c|c|c|}
\hline $\begin{array}{l}\text { Women } \\
\text { Beneficiaries }\end{array}$ & Human Effects & Social Effects & Technological Effects & $\begin{array}{l}\text { Infrastructural } \\
\text { Effects }\end{array}$ \\
\hline $\begin{array}{l}\text { Enabling } \\
\text { Practices }\end{array}$ & $\begin{array}{l}\text { Innovative practices } \\
\text { Social/voice } \\
\text { communications }\end{array}$ & $\begin{array}{l}\text { Convenience } \\
\text { Flexibility } \\
\text { Full payments } \\
\text { received } \\
\text { Agent trust } \\
\text { Symbolic tools of } \\
\text { freedom }\end{array}$ & SMS notifies payments & $\begin{array}{l}\text { Multiple cash-out } \\
\text { points }\end{array}$ \\
\hline $\begin{array}{l}\text { Constraining } \\
\text { Practices }\end{array}$ & $\begin{array}{l}\text { Digital / financial } \\
\text { illiteracy } \\
\text { Absence of skills and } \\
\text { training } \\
\text { Technophobia } \\
\text { User unfriendly } \\
\text { interface }\end{array}$ & $\begin{array}{l}\text { Agent fraud } \\
\text { High socio- } \\
\text { economic costs }\end{array}$ & $\begin{array}{l}\text { Mobile phones lost, } \\
\text { damaged or sold } \\
\text { SIMs blocked or lost } \\
\text { Mobile accounts not } \\
\text { registered against name } \\
\text { on identity card }\end{array}$ & $\begin{array}{l}\text { Weak signal } \\
\text { coverage } \\
\text { Power outages } \\
\text { Handset charging } \\
\text { problems }\end{array}$ \\
\hline
\end{tabular}




\subsubsection{Social Benefits and Constraints}

Full and Secure Payment vs. High Social and Economic Cost - The findings presented that mbanking enabled women to receive grants after receiving a notification - via a text message to their mobile phones. The text message embedded the PIN that was only known to the beneficiary for security purposes. Beneficiaries presented their PIN and computerized national identity cards (CNIC) to agents. The agent after verification authorized the payment after obtaining beneficiary's signature or thumb impression. Hence, digital payments provided beneficiaries the convenience and flexibility in receiving the full amount of grant from multiple cash-out points. Women felt relieved that they no longer had to bribe the local postmen to receive BISP payments.

I go to the agent to collect my grant and spend money on the travel, but it's still convenient for me as I can go anytime. I know the agent gives me all the money- he's a nice man. But once I forgot to take my identity card with me and it was a problem, as he didn't give the money so I had to go again (BISP beneficiary).

Despite the benefits of using mobile phones, women complained that it was too costly for them to travel to agent locations as they were not located nearby. As a result, a whole day was spent for collecting the grant. Due to sociocultural restrictions, beneficiaries were forbidden to travel alone, so usually were accompanied by relatives, friends or neighbours. They realized that traveling in groups was beneficial to share travel costs, and also overcome the social barriers associated with their traveling alone. As exclaimed by a beneficiary,

We have to travel long distances and are not allowed to travel alone so go in groups... also to share the cost of travel. It costs us a lot of time and money and when we come back home at the end of the day, we are still expected to do the housework and cook...it's not fair! (BISP beneficiary)

Agent Trust vs. Fraud - The majority of beneficiaries trusted banking agents who assisted them in the cash withdrawal process. Agents were praised for being helpful, as they voluntarily resolved any payment issues on the ground. Women confirmed that they handed their handsets and identity cards to agents, and received the full value of grant. The payments were secure as agents validated the PIN and verified their identities through biometric checks. In the end, beneficiaries were requested to give a thumb impression, or signature to confirm the receipt of payment.

Normally the agent is very helpful and I trust him because he's like my son, so I give my phone to him. He sees the message, asks for my CNIC card and thumb print, and after that, I get the money (BISP beneficiary).

However, there were few instances reported where dishonest agents 'pocketed' grants, and incorrectly informed beneficiaries that their monies had not arrived. As claimed by a BISP beneficiary, 
Some people did not get their money; agent told them that the money had not arrived and he kept it. We have heard stories like that as well, so it's not good (BISP beneficiary).

Such fraudulent agents were immediately identified by BISP management, and they were either suspended or their licenses were revoked. A BISP official remarked,

But if beneficiary does not receive the money, or if there are cases of fraud where agent takes the money, and the complaint is lodged with us, then we obviously take all franchises to task. Some franchises are suspended, some are blocked and the money is recovered if they do such a thing (Director Payments, BISP).

\subsubsection{Human Constraints}

Technical and Financial Illiteracy - As the majority of women were illiterate or semi-literate, they lacked digital and financial capabilities to use their mobile phones. Mostly, beneficiaries were even unable to read the local language, $U r d u$, or understand symbols, icons or numbers embedded in the text message/PIN on their mobile phones. Such lack of literacy and skills constrained m-banking usage, as stated by a beneficiary,

I have not been to school so it is difficult...initially I didn't understand what was the purpose of getting a mobile phone, but then my daughter or son would show me which buttons to press and I would barely manage....I still cannot read, send messages, or receive calls (BISP beneficiary).

A mobile operator official also exclaimed that illiteracy was the primary hurdle that restricted women from using mobile phones in the programme.

Literacy is a big barrier in Pakistan and not everybody is able to use a mobile phone. In fact, none of these beneficiaries are literate and none have mobile phones.... we did a survey initially to see how many people can even read and write and the numbers were terribly off! (Director, Easypaisa).

Moreover, it was learnt that women did not receive any informal digital and financial education, or training from BISP officers prior to receiving their mobile handsets. In addition, there was an absence of any local social mobilization campaign launched by management to create mobile phone usage awareness among women for receiving payments. As reported by a BISP beneficiary,

No... they did not tell us how to make or receive calls, or check messages on mobile phone for receiving the money. So I find it hard to use my phone and ask my son to dial the number even if I have to talk to someone (BISP beneficiary).

The Director of Payments also professed that owing to institutional constraints, BISP management failed to provide any digital training to beneficiaries.

We did not have the capacity to provide any training. Honestly, we did not have the facilities...so what we did was that we provided brochures and leaflets to the beneficiaries that had pictorial manifestation of the process. But if you specifically mean training, it wasn't there (Director Payments, BISP). 
Hence, human constraints created barriers for women to use their mobile phones independently. They typically sought help from relatives, neighbours or friends to read the text message and retrieve the PIN to show agent. As confirmed by a mobile operator official,

Mobile phones are changing hands...today she gives it to her brother, brother gives it to his son, son gives it to his wife, and so the handset has disappeared and is lying with someone else. So this is not a scalable model, nobody can invest in this (Director, Easypaisa).

Furthermore, it was learnt that some beneficiaries were techno-phobic, so were afraid of losing the payment by accidentally deleting the text message. For the very same reason, they also preferred not to carry their phones; in case it got lost so would the payment, as verified by a beneficiary,

I would never carry my mobile...I was once carrying it when it started beeping and I just didn't know what to do with it! So it is mostly at home, sometimes with my daughter or with someone else (BISP beneficiary).

User-Unfriendly Technology - The Director of Payments purported that m-banking was user unfriendly for women with reference to the complexity in human-technology interaction. It was observed that men from the same socio-economic class were more comfortable and competent in using mobile phones, while often, women struggled. Quoting in the Director's words,

But you have to keep in mind that our beneficiaries are basically women and technology is more male friendly (Director Payments, BISP).

A similar viewpoint was resonated by a mobile operator manager,

The design of m-banking is not female or gender friendly, so women struggle to use the technical features of the phone, read the SMS and enter the PIN number... women users are crippled by technology! (Manager, Easypaisa)

In order to make the m-banking interface more user friendly for women, BISP management had instructed that beneficiaries should receive an interactive voice recording (IVR) in the local language, $U r d u$, for payment notification, in addition to the text message. It was unveiled that women were not receiving the IVR that otherwise would have facilitated their usage of technology.

Besides receiving the text, women should also receive an IVR, and I know that probably beneficiaries are not receiving this...they were supposed to receive both (Director Payments, BISP).

\subsubsection{Technological and Infrastructural Constraints}

Mobile Phones, SIM and Account Issues - Mobile banking also imposed certain technological constraints related to the physical use of the technological artefact. Many beneficiaries complained that they were not offered replacement phones when their original handsets were 
damaged or lost. A banker noted that many women sold their mobile phones intentionally to earn extra money. Hence, it was not economically feasible to offer replacement handsets.

Mobile phones were reported as lost, but we saw that many poor beneficiaries sold their mobile phones! But banks could not give replacement handsets as it was too expensive for us (Senior Manager, Alfalah Bank).

Additionally, lost or blocked SIMs were other hurdles that constrained beneficiaries from cashing-out their grants from agents. As SIM cards were interchangeable and not tied to the specific handset, women were not bound to keep their phones. Also, they were able to receive payments by presenting the SIM cards without the handsets to agents. Thus, they felt no obligation to carry their phones at all times. As disclosed by a beneficiary,

The agent asks for my SIM and identity card if I don't have the handset. I give it to him and still receive the money, but once when the SIM got lost, there was a big problem (BISP beneficiary).

Other technological issues were related to mobile accounts getting blocked. This was common when a wrong mobile number was registered against a beneficiary's name which was inconsistent with the name presented on the identity card. The mobile account was blocked by the mobile operator for security purposes to ensure that payments were received by the legitimate beneficiary. As narrated by a beneficiary,

Once agent said that your account is blocked and your mobile number is not registered with your name. You know that they ask for an identity card, so a wrong mobile number was identified with my name, so I didn't get the money and was extremely upset! (BISP beneficiary)

Network Issues and Power Outages - In certain remote and rural populations around Rawalpindi and Islamabad, the mobile infrastructure was underdeveloped. Hence, weak signal and network coverage created problems for some beneficiaries to receive timely payment notifications. Also, there were complaints of frequent power outages in certain residential districts, so beneficiaries were unable to charge their handsets. This caused severe anxiety and distress to beneficiaries who encountered delays in receiving payments. As stated by a mobile operator manager,

Due to poor coverage and signal problems, beneficiaries do not receive the SMS on time, so some payments get delayed as many of them do not even have electricity at home (Manager, U-fone).

\subsection{Impact on Households}

This section illustrates how m-banking affected the socio-economic properties of households to answer the second research question located in the DoT framework (Table 4). 
Table 4: Effects of Mobile Banking on Household Structures

\begin{tabular}{|l|l|}
\hline Economic Effects & Social Effects \\
\hline Poverty Alleviation & Social Welfare \\
Cushioned poverty & Limited impact on education \\
Meeting basic needs & \\
\hline & \\
Financial Inclusion & Social and Political Inclusion \\
Negligible savings and asset investment & Empowerment \\
Limited access and usage of financial services & Socio-political transformation \\
Financial awareness and learning & \\
\hline
\end{tabular}

\subsubsection{Reduction in Poverty}

Meeting basic needs - The research showed that G2P payments - via m-banking supplemented household incomes and cushioned the effects of poverty in low-income households. Beneficiaries were grateful to BISP, as the money provided food security and raised their standard of living. A large proportion of the cash was spent on basic necessities: food, clothing and medicines. A beneficiary remarked,

The grant gives me a great feeling! I spend the money on food...like we can eat fruit now... and also on clothes and medicines, or any other important children's needs, but it's mostly used for the welfare of the entire household. I can sleep better at night now knowing that my children are not hungry anymore (BISP beneficiary).

This narrative was validated by a BISP Director,

They use the money to buy food, medicines and clothes.... and if you actually go into areas of rural Sindh, like Sukkur and Larkana, you will be surprised and shocked to see that some women don't even have sandals on their feet in the scorching sun...you cannot imagine but this is the level of poverty (Director Operations, BISP).

Majority of beneficiaries withdrew the grant instantaneously, within 2-3 days, after receiving it in their accounts. So, this illustrates their high dependency on BISP payments. Although the payments reduced poverty, the grants were insignificant to yield sustainable economic benefits to households.

Although we are getting more money and the extra money is helping us to buy food, clothes and medicines, we cannot see any significant change in our lives. The money is good, but not sufficient to drastically improve our economic conditions. As you know, there is inflation so things are becoming more expensive everyday...the Government does not control the rising prices of food and other commodities (BISP beneficiary). 


\subsubsection{Limited Financial Inclusion}

Negligible savings for education and asset investment - Many women complained that since the entire grant amount was spent to fulfil basic household needs, they could barely save any monies. As expressed by a beneficiary,

How can we save and do you really think it's possible? Savings is not a priority for us...I try to save, but end up using the whole amount of grant for the basic needs of the family. It's not a big amount anyways, so how can you expect any savings at the end of the month? (BISP beneficiary)

As many beneficiaries still struggled to cover household expenses within the meagre grant amount, affording primary education for their children was next to impossible. It was too costly for them to send their children to school and cover the educational expenses: school fees, books, uniforms and stationery. Thus, education was perceived as a 'secondary' need in comparison to hunger. A beneficiary quoted,

It's more important that we first fulfil our basic household needs...then we can think about educating our children....it is painful for me when I see other children going to school when mine don't (BISP beneficiary).

Moreover, due to negligible savings, beneficiaries were unable to invest in physical or capital assets - for example, buying agricultural machinery, livestock or sewing machines for engaging in micro-entrepreneurial activities. It was also disclosed that beneficiaries were not granted any loans from banks, or deposit/transfer payments from their accounts. Although mobile payments improved the economic well-being of many households, dependency on welfare payments continued to remain high. In this context, the Chairman at BISP exclaimed,

To-date unfortunately there aren't any key successes...we've just kept beneficiaries on a begging bowl! The last management on paper did train fifty seven thousand beneficiaries but there is no record, neither was there a plan of handling them after the training programme, and they've just been left on the streets without jobs! (Chairman, BISP)

Limited Access and Usage of Financial Services - Furthermore, it was revealed that beneficiaries in the program were offered 'limited purpose accounts' by banks. These were primarily conduit accounts which were confined to BISP withdrawals only. As the accounts were not 'financially inclusive,' they constrained women from undertaking financial transactions from their accounts. This included transferring funds, depositing savings and accessing microcredit/insurance from banks. This restriction on accounts constrained their economic participation and any incentives for engaging in micro-entrepreneurial activities. As professed by BISP officials,

Initially, whatever system we are running, it is a way towards financial inclusion, but it is not completely serving the purpose of financial inclusion because beneficiaries have limited purpose bank accounts to receive the G2P payments. In fact, these are rather conduit accounts because they are not allowed to carry out other transactions; they cannot receive or deposit 
money in that fund or account. So strictly speaking, it is not financial inclusion because we cannot talk about saving (Director Payments, BISP).

The most important thing is that we do not have any provision in our agreement with banks that virtual accounts maybe used for any other purpose. Even if some of the beneficiaries do not withdraw their money for a long time, banks don't provide any interest on their money, so this limits financial inclusion! (Outreach Manager, BISP)

Financial awareness and learning - Some BISP officials reinterpreted financial inclusion in terms of financial awareness and learning. It was observed that m-banking had fostered some basic awareness on mobile phone usage among women. Hence, owing to enhanced digital and financial literacy skills, a gradual rise in women's learning curves was noticed in the regions where beneficiaries resided. A BISP director exclaimed,

Financial inclusion is a little far ahead! Beneficiaries are mostly illiterate, so cannot use their mobile phones. They will make an effort to use technology and since they are determined to get their money, they will eventually learn. They have innovative minds...this is financial inclusion for us! Not that they can independently do financial transactions, but that they are developing the financial capabilities or capacities to read numeric data and use the PIN. This is the first stage of financial inclusion. The second stage involves being able to use the banking system independently (Director General Cash Transfers, BISP).

Hence, the themes from the data illustrate that m-banking reduced poverty in the short-term, but its long-term effects to restructure the economic properties of households, through financial inclusion, are marginal.

\subsubsection{Social Inclusion}

Empowerment -The study signified that m-banking led to social inclusion through the empowerment of women beneficiaries. This change was perceived to be transformative, as technology provided access to financial structures. Many women before had never participated in any financial process. A beneficiary exclaimed,

We never thought that one day, we can walk into a bank or an agents shop...banks are for the rich, so this has psychologically empowered us! (BISP beneficiary)

Many beneficiaries confessed that using mobile phones to receive BISP payments increased their self-esteem, as they became financially self-sufficient and less reliant on husbands' incomes. The possession of national identity cards, as mandatory requirement by BISP, marked their personal identities at home. Majority felt a sense of freedom and independence that augmented their social standing in households. One beneficiary remarked,

I feel more empowered and my self-esteem has increased, as I no longer need to ask family or relatives for help, so I feel self-sufficient and I can sense it. Also, because I have an identity card for receiving money, my husband knows that I have my own identity now, so he cannot be rude to me (BISP beneficiary). 
Socio-political transformation - Beneficiaries, even those from the most conservative households, were permitted to step out of their homes to collect BISP payments. In many patriarchal households, this signified a major shift in power dynamics and contributed toward social and political transformation. As validated by the Executive Vice President of a bank,

What we've seen by and large, even in supposedly very strong tribal areas that about eighty five to ninety percent of women, actually step out of their homes, and stand in lines, either at agent locations, or at franchise offices to withdraw their payments...so I think this is a significant social change that is happening, and there has been a huge social impact in communities (Executive Vice President, UBL).

Needless to say, national identity cards granted women the right to cast their votes, thereby, providing political freedoms to participate in national elections. Women, for the very first time, were registered as state citizens, which entitled them to other state services. As applauded by a beneficiary,

Having a CNIC card is a big thing for me, and I am very excited that I can vote now, as I have never voted before...I feel that it is a positive change happening politically for us (BISP beneficiary).

\section{Discussion}

In this section, the processes from the Duality of Technology framework (Section 3) are revisited to interpret the findings for the study.

\subsection{Technology is a Product and Medium of Human Action}

The Duality of Technology (Orlikowski, 1992) envisions that m-banking was socially constructed by BISP management in collaboration with stakeholders: banks, mobile operators and international agencies. Hence, technology inscribed certain interpretive schemes (Bijker and Law, 1992; Orlikowski, 1992) that facilitated BISP management to achieve institutional objectives of transparency, visibility and security in disbursing BISP payments. However, the 'duality of technology' implies how users, or women beneficiaries, enact technology through usage, so that it is not reduced to structural property of their households.

\subsubsection{Enabling and Constraining Effects of M-banking}

From women beneficiaries' perspectives, the main benefit of collecting payments - via mbanking was that they received the full amount of grant without bribing politicians, or postmen, to deliver the cash at home. Mobile banking enabled women to cash their grants at multiple 
pay-points, offering them convenience and flexibility in selecting the time/ place for collection. The PIN on the mobile phone was only known to the beneficiary, while biometric verification confirmed beneficiaries' identities for handing out payments securely. Hence, m-banking eliminated identity theft and introduced visibility in the payment disbursement process.

On the contrary, the m-banking design also embedded certain socio-economic constraints that limited beneficiaries' usage of technology. While technology offered freedoms to women by granting liberties to leave their homes for collecting payments, social and cultural restrictions barred many women from traveling alone. In order to overcome these barriers, beneficiaries preferred to travel in groups and share travel expenses which significantly reduced high economic/transaction costs. Through the lens of Duality of Technology, it is interpreted that social networks were re-structured around technology, as women organized themselves into groups. Hence, technology was 'appropriated' by women through the creation of new social practices that gave rise to social capital that resulted in cohesion. This theorizes interpretive flexibility' within DoT, as beneficiaries' recurrent engagements with technology reconstituted new social structures and practices in communities.

Moreover, the complex issue that emerged was that the majority of beneficiaries were digitally and financially incapable to use their mobile phones independently. Their low literacy and digital skills constrained their interactions with technology, so sought help from more literate members in their families/ communities to assist in the technical processes of m-banking. Although BISP management hoped to circumvent the entrenched traditional patronage structures, including middlemen from the disbursement process through technology, women still relied on 'male middlemen' mostly. While banking agents constituted another layer of human dependency for women, they were more esteemed and trusted over previous middlemen who were notorious for taking bribes. Banking agents helped them 'in benefit' of inputting and interpreting the PIN - 'proximate enabling' - and in the receipt of G2P cash - 'proximate translation.' Hence, they acted as bridges or 'intermediated users' to reduce the digital illiteracy gap between technology and users (Sambasivan et al., 2010).

Interpreting through DoT, technological constraints were embodied in the physical artefact of the mobile phone. Many cases of handsets being damaged or lost were common. Other issues including blocked SIM cards and mobile accounts posed other administrative issues for banking agents. In addition, infrastructural constraints (weak mobile coverage/ signal issues) were also embedded in the m-banking design. Frequent power outages in remote districts caused significant payment delays that resulted in anguish amongst beneficiaries. Moreover, beneficiaries were not receiving the interactive voice recording (IVR) for payment notifications that would have enabled them to surmount some illiteracy barriers. Needless to say, the digital interface was 'user unfriendly' for women, as technology design failed to consider users' digital and financial capabilities. In this vein, Gurumurthy (2004) highlights a gendered view on technology that is perceived to be 'masculine.' She argues that the exclusion of women in their engagements with technology is essentially ingrained within historical and cultural views of technology. This belief vindicates how traditional cultural values and practices exclude women's access to, and power over different technologies. Hence, the assumption that so- 
called gender-neutral technologies will benefit an entire population, may still remain a falsification (Hafkin, 2002; Spence, 2010). Through the lens of DoT, the interpretation that mbanking design needs to embed the capabilities of women users for increased technology usage is significant to overcome the digital gaps in societies.

Furthermore, DoT illuminates how m-banking had certain implications for beneficiaries; in providing little control over when and how to use their mobile phones, and with little discretion, over which meanings and elements influenced their usage and interactions with technology (Orlikowski, 1992). The notion of 'interpretive flexibility' reshaped new socio-technological practices within households. Beneficiaries appropriated technology for voice communications that amplified their social networks. Thus, the duality of technology prescribes how women 'enacted' technology through usage that shaped new social practices that went beyond management's expectations. Many beneficiaries visited internet cafés to learn about their payments. So, social practices were centered on technology within BISP communities. These practices nurtured new communication channels that cemented social and personal bonds of kinship and trust in local communities (Donner, 2006; 2007; Smith, Spence and Rashid, 2011).

\subsection{Institutional Impact of Technology on Structures}

Revisiting the prism of DoT explicates how m-banking aligned with existing financial processes to alleviate poverty, though it did not transform the economic properties of households for sustainable livelihoods.

\subsubsection{Limited Financial Inclusion}

Corresponding to the United Nations Millennium Goals for poverty alleviation, many governments in developing countries have set financial inclusion, as a fundamental policy goal, in digitizing G2P flows (Bold, Porteous and Rotman, 2012). The case study of the BISP in Pakistan showcased that transparency in delivering G2P payments was the primary objective for digitising BISP payments, while financial inclusion was a secondary goal.

Within the DoT framework, the relationship between m-banking and its effect on institutional properties of households is linked to beneficiaries' recurrent engagements with technology. At the household level, m-banking connected millions of unbanked households to the banking system. The provision of bank accounts to beneficiaries contributed toward financial inclusion. Porteous (2007) defined this as shift of access frontier 'outwards' - that was transformative. However, Morawczynski et al. (2010) argued that financial inclusion success should not only be limited to the withdrawal of payments from bank accounts. The term should also incorporate the usage of accounts for undertaking economic activities. Therefore, 'full financial inclusion' entails participating in a wide spectrum of financial transactions, such as depositing savings, accessing credit/insurance and making payments in the banking sector (Ehrbeck, 2011; Bold, Porteous and Rotman, 2012). 
The study illuminated that since banks offered accounts with 'limited functionality' to beneficiaries, they did not have access to 'financially inclusive' accounts for engaging in a range of economic activities. This restricted their participation in the micro-entrepreneurial sector, so 'limited' financial inclusion (Bold, Porteous and Rotman, 2012). Interpreting through DoT, the positive effects of technology on households were that women were seen to become more confident in their interactions with technology. Their awareness in handling financial matters considerably increased. As digital practices were enhanced to some degree, it was interpreted as being the first step on the financial inclusion ladder. Through the lens of DoT, it is argued that m-banking 'reinforced' or aligned with existing economic practices for poverty alleviation, although it failed to 'transform' the structural properties of households for financial inclusion. Financial inclusion is the intermediary step for poverty graduation. So realistically speaking, financial inclusion was still in the infancy stage, as beneficiaries' access to a wider range of financial services was limited for undertaking economic activities in BISP communities in Pakistan.

\subsubsection{Socio-Political Inclusion was Transformative}

From a social aspect, it is argued that mobile phones were symbolic tools for transforming the social properties of beneficiaries' households - related to well-being and freedom. Hence, social inclusion was transformative. Although beneficiaries handed over their mobile phones to family members, typically husbands, they still felt empowered by possessing identity cards. Moreover, m-banking provided access to new structures and processes for receiving BISP payments that psychologically empowered women in their households. Hence, DoT interprets that technology created new social structures and practices that shifted familial power within households. Identity cards elevated beneficiaries' social standing in households, as they were less reliant on husband's income. This led to their financial independence which augmented their decision-making roles in the house. So, DoT theorizes how the power equilibrium was affected to impact on social dynamics within the household. Furthermore, beneficiaries' enrolment as state citizens and their entitlement to vote signified a political change. Hence, socio-political inclusion, interpreted through DoT, restructured the social and political landscape in BISP communities. Since the diffusion of technology was guided by the application of normative sanctions within households, moral order was articulated and sustained through rituals, traditions and practices that legitimized social practices (Orlikowski, 1992). Although m-banking enhanced personal freedoms of poor women beneficiaries, it failed to build human and financial capacities for sustainable and inclusive development of communities.

\section{Conclusions and Contributions to Knowledge}

In this study, the social construction of m-banking was driven by management's objectives to achieve transparency in the delivery of G2P payments, while financial inclusion was a secondary agenda for BISP managers. Whilst m-banking provided opportunities to achieve 
financial inclusion of unbanked households, the DoT framework also illuminated how digital technologies embedded certain human, socio-economic and technological constraints that 'limited financial inclusion' in BISP households. The paper concludes that m-banking practices were 'palliative' to reduce poverty in households. However, technology was inept to 'structurally transform' the economic properties for eliminating poverty through 'full financial inclusion.' This is important because financial inclusion is perceived as an intermediary stage for poverty graduation in households.

Whilst highlighting user's challenges with their interactions with technology, and how technology design restricted financial inclusion in poor households, this paper does not question the merits of digital innovation in G2P programs. There are still many benefits realized for users and management in the G2P ecosystem. However, it is necessary to highlight that while implementing complex digital programs, managers must be aware of the critical problems that may impact on socio-economic practices in communities. Thus, digital innovation may not always be deemed as the perfect solution or 'silver bullet' for development, without recognizing the 'side effects.' While this paper draws attention to the social inclusion aspect of technology, many G2P programs in future may benefit from shifting to digital payment platforms for social cash disbursements.

First, the theoretical contribution of the paper offers valuable insights and extends the ICT innovation literature that is informed through DoT. While highlighting the myriad sociotechnical issues on m-banking usage that has implications on financial inclusion, the DoT framework sheds light on how the capabilities vision may be inscribed in technology. This helps us to better understand the complex interactions between technology and human agents (Sen, 1999; Zheng, 2009; Kleine, 2009; Andersson, Grönlund and Wicander, 2012). Hence, the DoT framework bridges the gap between theory and practice by proposing how future ICT programs may be designed while keeping in mind the capabilities of users, so that technology becomes less deterministic for them.

Second, this paper suggests some practical implications for governments and policy makers in the G2P payment sector. Before embarking on digital programs, it is necessary for program managers to offer comprehensive digital and financial skills training to users. This would help build users' capabilities for using technology, and ultimately, reduce digital poverty. In future, social cash managers and m-banking providers may consider using a bottom-up and participatory approach, involving users during the design and construction of technology. This would enable the design of more user-friendly digital interfaces to foster pro-poor growth at the Bottom of the Pyramid (Heeks, 2009; 2010). In addition, m-banking providers may deploy more flexible m-banking models that increase user's access to a variety of financial services. This may lead to inclusive innovation and support entrepreneurial development in financially underserved communities (Foster and Heeks, 2013; Heeks, Foster and Nugroho, 2014). Other financial institutes may exploit or 'ride on' the G2P infrastructure set up by the government and offer micro credit to beneficiaries. This will be useful to evoke the micro-entrepreneurial spirit through a 'trickle down' effect from the G2P sector. These are some lessons the paper 
provides for governments, policy-makers and practitioners working on digital innovation projects in developing countries.

Finally, this paper explored a socially important and internationally acclaimed m-banking program in Pakistan through the lens of an established research framework. The considerations from this study feed both into the ICT innovation and development literature to offer invaluable insights on a popular topic in the G2P sector that was previously under-researched. By exploring the social, economic and technological issues around the usage and impact of $\mathrm{m}$ banking, this paper advances the conceptualization on inclusive innovation and development of poor communities in developing countries.

Whilst the novelty in drawing on a unique case in Pakistan may be regarded as a methodological strength on its own, given that the sites for data collection were confined to two geographic locations may be a limitation for this study. To some extent, this may have limited the ability to generalize the findings; however, analytical generalization is evident (Walsham, 1995). This applies to this case where concepts were developed and implications were drawn for interpreting $\mathrm{m}$-banking usage and implications, specifically, for the BISP, and more generally, for other G2P programs with similar contextual environments. Moreover, other limitations of locating the study within the interpretive paradigm in order to 'make sense' and gain deep insights on complex m-banking issues means the absence of measuring testable propositions across wider populations. However, the aim of the interpretive study was to achieve outcomes that were transferrable and reliable, in lieu of making generalizable conclusions. So when the research understanding is extended to cases in similar environments, it is important to take note of the specific particularities of the new context (Walsham, 1995).

Furthermore, the study offers potential for conducting research on other lucrative themes within the case to further contribute to the ICT4D literature. The study presented that debit cards were replacing mobile phones in the m-banking regions. So, in future, it may be useful to evaluate the usage of these digital instruments to impact on women's livelihoods. Since little, if any, research in the past has analyzed the scaling of digital interventions in the G2P sector, future research may also precisely look at how debit cards were scaled across the country. This is vital to explore, as most ICT innovations relate to structures and processes whilst ignoring issues of scalability.

\section{Acknowledgements}

I would like to sincerely thank the management at the Benazir Income Support Programme in Pakistan, and staff from financial institutions, mobile operators and DFID, for their kind assistance for data collection in Pakistan. I am also very thankful to the Editors and Reviewers of the Information Technology for Development Journal for offering their valuable insights on this paper. 


\section{Funding}

The author is extremely grateful to her institution, Anglia Ruskin University, UK for providing indefinite support for this study.

\section{Notes on contributors}

Dr. Atika Kemal is an Associate Lecturer in the Lord Ashcroft International Business School at Anglia Ruskin University, United Kingdom. Her research interests focus on digital innovation and management, ICTs for inclusion and socio-economic development, digital economies and digital social innovation. She has published in Association of Information Systems electronic library (AISeL) and has presented at several international conferences, including European Conference of Information Systems (ECIS). Dr. Kemal holds a PhD from Anglia Ruskin University and MSc in Management and Information Systems from the London School of Economics and Political Science, UK. She is an Associate Fellow of the Higher Education Academy (HEA), UK.

\section{References}

Almazan, M. (2013). G2P Payments and Mobile Money: Opportunity or Red Herring? GSMA [blog]. Available at: http://www.gsma.com/mobilefordevelopment/g2p-payments-mobilemoney-opportunity-or-red-herring

Andersson, A., Grönlund, Å. and Wicander, G. (2012). Development as Freedom-How the Capability Approach can be Used in ICT4D Research and Practice. Information Technology for Development, 18(1), pp. 1-4.

Anwar, Y., ed. (2013). Mobile Banking in Pakistan. Proceedings of Sixth International Conference on 'Mobile Banking in Pakistan' - Karachi, Pakistan, March 2013.

Avgerou, C. (2002). The Institutional Nature of ICT and Organizational Change. In: C. Avgerou, ed. 2002. Information Systems and Global Diversity. Oxford: Oxford University Press. Chapter: 1, pp.1-38.

Avgerou, C. (2010). Discourses on ICT and Development. Information Technologies and International Development, 6 (3), pp. 1-18.

Bankable Frontier Associates. (2009). Promoting Financial Inclusion through Social Transfer Schemes. [pdf] Report commissioned by the UK's Department for International Development (DFID): Boston, MA. Available at: http://bankablefrontier.com/assets/pdfs/BFA-G2P-DFIDWkshpPaper-FinalPDF-M-Nov08.pdf 
Baro, E. E., and Endouware, B. E. C. (2013). The Effects of Mobile Phone on the SocioEconomic Life of the Rural Dwellers in the Niger Delta Region of Nigeria. Information Technology for Development, 19 (3), 249-263.

BISP Report (2014). Brief on Benazir Income Support Programme (BISP): A Social Safety Net. www.bisp.gov.pk. Government of Pakistan, Pakistan.

Bijker, W.E. and Law, J. (1992). Shaping Technology/ Building Society: Studies in Sociotechnical Change. [E-book] The MIT Press. Available through: Google.

Blackwell, C. (2014). Teacher Practices with Mobile Technology: Integrating Tablet Computers into the Early Childhood Classroom. Journal of Education Research, 7 (4), 1-25.

Bold, C., Porteous, D. and Rotman, S. (2012). Social Cash Transfers and Financial Inclusion: Evidence from Four Countries. CGAP, Washington, D.C.

Boyatiz, R.E. (1998). Transforming Qualitative Information: Thematic Analysis and Code Development. Thousand Oaks, CA: Sage.

Bras, J., Aldewereld, H., Verburg, Q., Warnier, M. and Janssen, M. (2016). The Duality of Technology: ICT as an Enabler and Inhibitor in Business Process Improvement. AIS Electronic Library (AISeL). http://aisel.aisnet.org/amcis2016/SocialTech/Presentations/9/

Braun, V. and Clarke, V. (2006). Using Thematic Analysis in Psychology. Qualitative Research in Psychology, (3), pp. 77-101.

Cruz, P., Neto, L.B.F., Muñoz-Gallego, P. and Laukkanen, T. (2010). Mobile Banking Rollout in Emerging Markets: Evidence from Brazil. International Journal of Bank Marketing, 28 (5), pp.342-371.

CGAP. (2011). Technology Program Note Pakistan, 2011. Washington, D.C.: CGAP, http://www.cgap.org/sites/default/files/CGAP-Technology-Program-Country-Note-PakistanApr-2011.pdf

CGAP. (2012). Interoperability and the Pathways towards Inclusive Retail Payments in Pakistan, 2012. Washington, D.C.: CGAP, Bankable Frontier Associates.

CGAP. (2010). Mobile Banking for those with no Mobile. Washington, D.C.: Available at: http://www.cgap.org/blog/mobile-banking-those-no-mobile

Demirguc-Kunt, A., Klapper, L., Singer, D. and Oudheusden, P.V. (2014). The Global Findex Database. Measuring Financial Inclusion around the World. Policy Research Working Paper 7255. World Bank, Washington, DC. Available at: http://www.worldbank.org/globalfindex 
Donner, J. and Tellez, C.A. (2008). Mobile Banking and Economic Development: Linking Adoption, Impact, and Use. Asian Journal of Communication, 18 (4), pp.318-332.

Donner, J. (2006). The Use of Mobile Phones by Micro-entrepreneurs in Kigali, Rwanda: Changes to Social and Business Networks. Information Technologies and International Development, 3 (2), pp.3-19.

Donner, J. (2007). M-banking and M-payments Services in the Developing World: Complements or Substitutes for Trust and Social Capital. Preconference on Mobile Communication at the 57th Annual Conference of the Int. Communication Association [online] San Francisco, California, May 2007.

Duncombe, R. and Boateng, R. (2009). Mobile Phones and Financial Services in Developing Countries: A Review of Concepts, Methods, issues, Evidence and Future Research Directions. Third World Quarterly, 30 (7), pp.1237-1258.

Ehrbeck, T. (2011). Financially Inclusive Ecosystems: The Role of Government Today. CGAP. Washington, D.C.

Ehrbeck, T., Pickens, M. and Tarazi, M. (2012). Financially Inclusive Ecosystems: The Roles of Government Today. CGAP No. 76: World Bank. https://www.cgap.org/sites/default/files/Focus-Note-Financially-Inclusive-Ecosystems-TheRoles-of-Government-Today-Feb-2012.pdf

Emmett, B. (2012). Electronic Payment for Cash Transfer Programmes: Cutting Costs and Corruption or an Idea Ahead of its Time? Pension Watch Briefing 8. London: Help Age International.

Firpo, J. (2009). E-Money- Mobile Money-Mobile Banking- What's the Difference? The World Bank (blog). Available at: http://blogs.worldbank.org/psd/e-money-mobile-moneymobile-banking-what-s-the-difference

Foster, C. and Heeks, R. (2013). Conceptualizing Inclusive Innovation: Modifying Systems of Innovation Frameworks to Understand Diffusion of New Technology to Low-Income Consumers. European Journal of Development Research, 25, pp. 333-355.

Giddens, A. (1990). "Structuration Theory and Sociological Analysis," in Anthony Giddens: Consensus and Controversy, J. Clark, C. Modgil, and J. Modgil (eds.), Brighton: Falmer Press.

Giddens, A. (1991). "Structuration Theory: Past, Present and Future," in Giddens' Theory of Structuration: A Critical Appreciation, C. G. A. Bryant and D. Jary (eds.), London: Routledge, pp. 201-221. 
GSMA. (2014). Code of Conduct for Mobile Money Providers. Report available at: https://www.gsma.com/mobilefordevelopment/programmes/mobile-money/policy-andregulation/code-of-conduct

Gurumurthy, A. (2004). Gender and ICTs. Institute of Development Studies, BRIDGE Report.

Hafkin, N. (2002). Is ICT Gender Neutral? A Gender Analysis of Six Case Studies of Multi Donor ICT Projects. Santo Domingo, Dominican Republic: United Nations International Research and Training Institute for the Advancement of Women (INSTRAW).

Heeks, R. (2009). Emerging Markets IT and the World's "Bottom Billion": Communications of the ACM, 52 (4) pp.22-24.

Heeks, R. (2010). Do Information and Communication Technologies (ICTs) Contribute to Development? : Journal of International Development, 22 (5) pp.625-640.

Heeks, R., Foster, C. and Nugroho, Y. (2014). New Models of Inclusive Innovation for Development. Innovation and Development, 4 (2) pp. 175-185.

Jones, M. R. (1999). "Structuration Theory," in Re-thinking Management Information Systems, In: W. J. Currie and R. Galliers (eds.), Oxford: Oxford University Press, pp. 103135.

Jones, M. R., and Karsten, H. (2008). Giddens's Structuration Theory and Information Systems Research. MIS Quarterly, 32(1), pp. 127-157.

Jones, M., Orlikowski, W., and Munir, K. (2004). Structuration Theory and Information Systems: A Critical Reappraisal. Social Theory and Philosophy for Information Systems, pp. 297-328.

Klapper, S. and Singer, D. (2014). The Opportunities of Digitizing Payments: How digitization of payments, transfers, and remittances contributes to the G20 goals of broadbased economic growth, financial inclusion, and women's economic empowerment. World Bank Development Research Group Report: Washington D.C.

Kleine, D. (2009). The Ideology behind the Technology - Chilean Micro-entrepreneurs and Public ICT Policies. Geoforum, Journal of Physical, Human, and Regional Geosciences, 40. pp. 171-183.

Mas, I. (2009). The Economics of Branchless Banking. Innovations: Technology, Governance, Globalization, 4 (2), pp. 57-75.

Mas, I. (2012). Transforming Access to Finance in Developing Countries through Mobile Phones: Creating an Enabling Policy Framework. Banking and Finance Law Review [online], 27 (2), pp. 285- 298. 
Morawczynski, O., Hutchful, D., Rangaswamy, N. and Cutrell, E. (2010). The Bank Account is not Enough: Examining Strategies for Financial Inclusion in India. Proceedings from ICTD2010, December 13-15, London, UK.

Mota, Flávio Perazzo Barbosa, \& Rodrigues Filho, José. (2011). Public E-procurement and the Duality of Technology: A Comparative Study in the Context of Brazil and of the State of Paraíba. JISTEM - Journal of Information Systems and Technology Management, 8(2), 315330.

Naveed, A. and Ali, N. (2012). Clustered Deprivation: District Profile of Poverty in Pakistan, SDPI Report, Pakistan.

Oberländer, L., and Brossmann, M. (2014). Electronic Delivery Methods of Social Cash Transfers. Discussion Papers on Social Protection [pdf]. Available at: https://www.giz.de/fachexpertise/downloads/giz2014-en-electronic-delivery-methods-ofsocial-cash-transfers.pdf

Orlikowski, W.J. (1992). The Duality of Technology: Rethinking the Concept of Technology in Organisations: Organization Science, Focused Issue: Management of Technology, 3 (3) pp.398-427.

Pakistan Economic Survey. (2014/15). Highlights. [pdf]. Islamabad: Economic Adviser's Wing. Finance Division, Government of Pakistan. Available at: http://www.finance.gov.pk/survey/chapters_15/Highlights.pdf

Pickens, M, Porteous, D. and Rotman, S. (2009). Banking the Poor via G2P Payments. CGAP, Washington, D.C.

Pinsonneault, A., and Kraemer, K. L. (2002). Exploring the Role of Information Technology in Organizational Downsizing- A Tale of Two American cities. Organization Science, 13 (2), pp. 191-208.

Porteous, D. (2006). The Enabling Environment for Mobile Banking in Africa. London, UK: Department for International Development.

Porteous, D. (2007). Just How Transformational is M-banking. FinMark Trust. Available at: <http://www.finscope.co.za/documents/2007/transformational_mbanking.pdf> [Accessed 1 March 2013].

Qureshi, S. (2014a). Overcoming Technological Determinism in Understanding the Digital Divide: Where Do We Go From Here? Editorial. Information Technology for Development 20 (3), pp.215-217. 
Qureshi, S. (2014b). Theory to Inform Practice or to Build Theory: Are Emerging Economies in a Cyclical Relationship with their Information and Communication Technologies? Editorial. Information Technology for Development, 20 (4), pp. 293-295.

Rahul De' and Ratan, A.L. (2009). Whose Gain is it Anyway? Structurational Perspectives on Deploying ICTs for Development in India's Microfinance Sector. Information Technology for Development, 15 (4), pp. 259-282.

Rotman, S. (2011). So Where Are We in the Link Between G2P and Financial Services? CGAP, Washington, D.C.

Rotman, S., Kumar, K. and Parada, M. (2013). An Overview of the G2P Sector Payments in Pakistan. CGAP, Washington, D.C.

Sambasivan, N., Cutrell, E., Toyama, K. and Nardi, B. (2010). Intermediated Technology Use in Developing Communities. Proceedings from CHI 2010: HCI and Developing World, April 10-15., pp. 2583- 2592.

Sen, A. (1999). Development as Freedom. Oxford: Oxford University Press.

Shaikh, A.A. and Karjaluoto, H. (2015). Mobile Banking Adoption: A Literature Review. Telematics and Informatics, 32, pp. 129-142.

Sjöberg, A. (2013). Making Sense of a Technology: A study of how professionals use, understand and create a sense of Facebook, LinkedIn and Twitter and what factor' s that might influence these processes. https://gupea.ub.gu.se/handle/2077/31935

Spence, N. (2010). Gender, ICTs, Human Development, and Prosperity. Information Technologies \& International Development, 6 (Special Edition), pp.69-73.

Smith, M.L., Spence, R. and Rashid, A.T. (2011). Mobile Phones and Expanding Human Capabilities. Information Technologies \& International Development, 7 (3), pp.77-88.

Strauss, A. and Corbin, J. (1999). Basics of Qualitative Research. 2nd ed. Thousand Oaks, CA: Sage.

Stuart, G. (2016). Government to Person Payments: On Ramp to Financial Inclusion? Center for Financial Inclusion: Washington D.C.

Taylor, G.W. and Ussher, J.M. (2001). Making Sense of S\&M: A Discourse Analytic Account. Sexualities, 4, pp. 293-314.

Thompson, M. (2008). ICT and Development Studies: Towards Development 2.0: Journal of International Development, 20, pp.821-835. 
Vincent, K. and Cull, T. (2011). Cell phones, Electronic Delivery Systems and Social Cash Transfers: Recent Evidence and Experiences from Africa. International Social Security Review, 64 (1), pp. 37-51.

Walsham, G. (1995). The Emergence of Interpretivism in IS Research. Information Systems Research, 6 (4), pp.376-394.

Walsham, G. (2006). Doing Interpretive Research. European Journal of Information Systems, 15 , pp.320-330.

Wessels, L. and Drennan, J. (2010). An Investigation of Consumer Acceptance of M-banking. International Journal of Bank Marketing, 28 (7), pp. 547-568.

World Bank. (2014). Data on Mobile Cellular Subscriptions. [online]. Available at: http://data.worldbank.org/indicator/

Yin, R.K. (2009). Case Study Research: Design and Methods. $5^{\text {th }}$ Edition. Thousand Oaks, CA: Sage.

Zheng, Y. (2009). Different Spaces For E-development: What Can We Learn from the Capability Approach? : Information Technology for Development, 15 (2) pp.66-82. 
Information Technology for Development Journal 